Scientific Electronic Archives

Issue ID: Sci. Elec. Arch. Vol. 12 (5)

October 2019

DOI: http://dx.doi.org/10.36560/1252019791

Article link

http: / / www.seasinop.com.br/revista/index.php?journal=SEA\&page=a $\underline{\text { rticle\&op=view\&path } \% 5 B \% 5 \mathrm{D}=791 \% \text { path } \% 5 B \% 5 \mathrm{D}=\mathrm{pdf}}$

Included in DOAJ, AGRIS, Latindex, Journal TOCs, CORE, Discoursio

Open Science, Science Gate, GFAR, CIARDRING, Academic Journals

Database and NTHRYS Technologies, Portal de Periódicos CAPES.

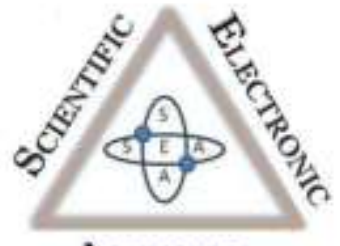

Archives

ISSN 2316-9281

\title{
Postharvest losses of guava in the retail trade at Chapadinha (MA)
}

\author{
M. S. Mendes, F. M. S. Chaves, S. S. Nascimento, I. C. G. Pires, E. I. B. Almeida, A. N. S. Sousa, G. E. \\ Ferrão
}

Universidade Federal do Maranhão - UFMA

\section{Author for correspondence: mayara.out@hotmail.com}

\begin{abstract}
As it is climatic fruit, guava has a short postharvest shelf life, that limits its marketing. The aim of the present work was to conduct a survey about the commercialization scenario and estimation of postharvest losses of guava in Chapadinha (MA). The research carried out in November 2016, through interviews in 12 groceries stores and 2 supermarkets in the city of Chapadinha (MA). For this, a questionnaire consisting of 13 objective questions that covered aspects about the origin, trading volume, causes, and estimation of guava losses was used. At the end of the study, it was found that $95 \%$ of guava sold in Chapadinha comes from the city of Tianguá (CE). Postharvest losses were estimated at $21 \%$ for supermarkets and $17 \%$ groceries stores. Physiological (accelerated ripening) and mechanical (kneading) factors were mainly responsible for guava losses. The damage caused can be mitigated by the adoption of good post-harvest practices and administrative management, which have the potential to be disseminated by training courses.
\end{abstract}

Key words: Economy, Fruticulture, Handling, Planning, Psidium guavaja.

\section{Introduction}

Guava is originally from South America and was dispersed worldwide by European seafarers. (EMBRAPA, 2010). In Brazil, crop occupies an important place in agribusiness and characterizes the country as one of the largest producers in the world (QUINTAL, 2013; SEBRAE, 2016). According to the Brazilian Yearbook of Agriculture (AGRIANUAL, 2015), Brazilian production of guavas was 424.305 tons, the Northeast and Southeast regions were the largest producers, with 207.169 and 179.310 tons, respectively.

In Brazil, guava is grown in three very distinct production systems: table guava, industrial guava, and mixed crops. The mixed crops purpose to supply both markets simultaneously, which is interesting to producers, once the best quality are destined to the fresh fruit market (RAMOS et al., 2011).

As it is climacteric fruit, guava has a short postharvest shelf life, in other words, it has an increase in ethylene production and of the respiratory rate, after plant shutdown. This culminates in rapid loss of firmness and high incidence of rotting (SINGH \& PAL, 2008).
These characteristics limit the potential of storage, marketing, and exportation of the fruit, being one of the factors responsible for the inexpressive volume exported by the country BRAZILIANFRUIT, 2013).

Research in techniques to preserve the quality of guava is very important because it would allow a longer period of commercialization and, especially, would enable the transport of fruits over long distances, such as maritime transport, aim exportation, as well as the improper conditions that are exposed in its commercialization or lack of adequate storage (BRACHMANN et al., 2012).

There are two types of food disposal: loss and waste. Loss is characterized by do not direct food to consumption due to injuries that alter its physical, chemical, microbiological or organoleptic properties, such as kneading, cutting, senescence, rotting, among other factors. On the other hand, waste occurs when food is discarded when it still has adequate conditions for consumption (ALMEIDA et al., 2012; SOUZA et al., 2018).

In supermarkets and Ceasas (Supply Center), many foods are discarded only considering the appearance of the product. Besides throwing away tons of food that could serve to end hunger in 
several parts in the world, not using food is also a waste of natural resources such as water, soil, labor and farmer financial resources (SEBRAE, 2011; SANTOS \& VIEIRA, 2011; ALMEIDA et al, 2012). During the marketing process, there are several postharvest losses, which may be due to factors inherent to normal metabolisms of the product or external factors, as improper cultivation, transport and handling practices with packaging in a wooden crate and handling by untrained persons. (SENHOR et al., 2009; GONÇALVES, 2014).

Postharvest losses of agricultural products are associated with mechanical and physiological injuries (PARISI et al., 2012). Among the mechanical damages, it is common the occurrence of impacts, abrasions, compressions and small cuts (SILVA et al., 2015). Physiological disorders are losses related to high respiration rate, ethylene production, mass loss, tissue softening, flavor loss and nutritional value (CHITARRA; CHITARRA, 2005). The marketing environment becomes indispensable to extend the shelf life of the fruits. After harvest, the gradual loss of turgidity of the fruit tissues begins, decreasing the quality until the point where the product becomes a source of nutrients for pathogens, increasing its deterioration (SANTOS FILHO et al., 2014).

Thus, analyzing the local scenario is of utmost importance since post-harvest losses significantly affect the profitability of the markets involved. Therefore, the present work was developed with the aim to conduct a survey about the commercialization scenario and estimation of guava postharvest losses in Chapadinha-MA.

\section{Methods}

The survey was conducted in Chapadinha (MA), in November 2016, interviewing 14 traders, 2 were supermarket owners and 12 were groceries owners. The determination of the number of markets used was based on the previous analysis, with the municipal Sanitary Surveillance agency, that holds the number of registered markets in the vegetables and fruits segment. There are 14 supermarkets and 52 groceries store whose sample corresponded to 14.28 and $23.08 \%$ of the total respectively.

For the interviews, a questionnaire based on Almeida et al. (2012), consisting of 13 objective questions, that covered aspects about the origin, volume purchased, volume sold and postharvest guava losses. Traders pointed out, through objective questions, the main causes of guava injury. In the quantification of the results, it obtained the mean percentage of action of these causal agents, with subsequent calculation of the relative interference percentage over the total estimated percentage of losses.

The results were analyzed by descriptive statistics, and the losses were expressed in percentage (\%), presented in tables, in which the mean loss of each vegetable was associated with the relative percentage of causal factor performance. Thus, postharvest losses were called physiological and mechanical losses. In relation to the mean percentage of losses, it estimated the mean standard error and variation coefficient in order to define the experimental precision. The volume of fruit offered was estimated as the sum of the quantity offered, in kilograms per week, available for sale in the 14 establishments analyzed.

\section{Results and discussion}

The origin of guava offered in Chapadinha (MA) commercial establishments is especially from Tianguá (CE), which represents $95 \%$ of the total origin. This city is located $397.7 \mathrm{~km}$ away from Chapadinha (MA), but for the privileged geographical position and the limitation of fruit from Maranhão, offers a large volume of guava. Although it does not stand out as an important producing region of this and other fruits. The remaining portion (5\%) comes from Bahia and Piauí. These results were similar to those obtained by Amorim et al. (2016) and Ferrão et al. (2016), who found that, on average, $90 \%$ of the fruits commercialized in the Chapadinha microregion come from Ceará. According to Vieira et al. (2008), guava offers.

several options for use, but is highly perishable Its physiological processes are aggravated by the limitations of transport conditions, handling, and marketing. Thus, the potential for guava postharvest losses can be increased by long distances traveled, on limited road networks (TOMM et al., 2016) and adverse weather conditions such as heavy rain in the rainy summer (December to May) and high temperatures in the dry winter (June to November). This makes the guava susceptible to mechanical damage and physiological disorders, respectively. Evidence corroborates with Ceccato \& Basso (2012), who stated that inadequate transportation of perishable products, such as guava, might cause problems in maintaining its quality. (For the groceries segment, there was an acquired volume of $317 \mathrm{~kg}$ per week (Table 1). In an extrapolation of the data, given the total number of groceries stores registered in Chapadinha, there would be a purchased volume of $1.479 \mathrm{~kg}$ per week, which would correspond to almost 6 tons per month. This demonstrates the importance of guava to the retail market of the city, as a stimulant of income generation and jobs.

However, of this volume purchased weekly, the portion traded was only83.00\% (263.5 kg), whose remaining $17.00 \pm 3.07 \%(53.5 \mathrm{~kg})$ were lost. Among the main causes are physiological disorders, which were estimated at $14.00 \%$ and represented $82.35 \%$ of the origin of total losses in guava. The remaining losses were due to mechanical injuries (Table 1).

According to Guerra et al. (2017), although mechanical losses are analyzed individually, they may have contributed to increased guava metabolic activity, with inherent losses to commercialization. In 
view of adverse environmental conditions with a mean temperature of $28^{\circ} \mathrm{C}$ and low relative humidity, 67\%, the ethylene synthesis, and respiration may increase, promoting the rapid ripening of the fruit.

The estimated total mean loss for guava corroborates with Nascimento et al. (2016), who estimated a total loss of $20.70 \%$, with physiological losses of $14.1 \%$, also in Chapadinha (MA). According to Tietfel et al. (2012) and Silva et al. (2013), physiological disorders are associated with accelerated fruit ripening and probably it originated from inadequate transportation, storage and marketing conditions. In the present study, it was estimated that approximately $97 \%$ of traders do not adopt storage practices to promote a higher postharvest guava shelf life.

In Chapadinha (MA), guava is commercialized under room temperature and humidity conditions. This may interfere directly the ethylene synthesis, which is one of the main factors responsible for the accelerated ripening of climatic fruits (SENAI, 2016). According to Brunini and Cardoso (2011), and Rocha et al. (2007), is an efficient way to increase the shelf life of guava, as it provides a reduction in its metabolism, water loss and consequent maintenance of fruit quality attributes.

In relation to supermarkets, the volume purchased and sold corresponds to 27 and $22 \mathrm{~kg}$ per week, respectively (Table 2 ). In an extrapolation to the total number of supermarkets registered in Chapadinha (MA), the volume purchased would be $54 \mathrm{~kg}$, while the sold would be $44 \mathrm{~kg}$ per week, equivalent to less than one ton per month.

This highlight that the groceries stores are more relevant to the marketing of vegetables in
Chapadinha (MA), which was expected by the specificity of the segment.

Total guava losses in supermarkets were estimated at $21.00 \pm 2.48 \%$, of which $10.5 \%$ came from physiological disorders and $10.50 \%$ from mechanical damage (Table 2).

The estimated total loss results for guava in supermarkets corroborate Cristofoli et al. (2014), which quantified $16.8 \%$ of postharvest guava losses sold in supermarkets in Fortaleza (CE).

For supermarkets, the higher magnitude of guava losses likely is associated with mismanagement of available resources and the amount offered, since is observed the society tends to look more often for groceries stores to buy fruits and vegetables than supermarkets. These evidences are emphasized by Amorim et al. (2017), who highlighted the groceries stores as the main market segment for fruit and vegetables in Chapadinha (MA), especially due to the price and quality of the products.

That is, products that stay longer on shelves are more susceptible to physiological disorders, this culminates in their unavailability for consumption and commercialization, especially when they arrive at markets in advanced maturation stages. Regarding mechanical damage, the losses may start from product delivery due to poor standardization in packaging boxes, which sensitizes friction on roads, whose are considered in precarious conditions in Maranhão (MA), until its final commercialization. In addition, improper handling and consumer habits when they select guava on the shelf can be further a factor in the estimated losses.

Table 1 - Volume Acquired, traded and losses recorded during guava commercialization in groceries stores at the Chapadinha (MA), 2016.

\begin{tabular}{|c|c|c|c|c|c|}
\hline \multirow{2}{*}{ Fruit } & \multirow{2}{*}{$\begin{array}{c}\text { Vol. } \\
\text { Acquired } \\
(\mathrm{kg})\end{array}$} & \multirow{2}{*}{$\begin{array}{c}\text { Vol. } \\
\text { Commercialized } \\
(\mathrm{kg})\end{array}$} & \multirow{2}{*}{$\begin{array}{c}\mathrm{PT} \pm \mathrm{e} \\
(\%)\end{array}$} & \multicolumn{2}{|c|}{ Causes of Losses (\%) } \\
\hline & & & & Physiological & Mechanical \\
\hline Guava & 317 & 263 & $17.00 \pm 3.07$ & 14.00 & 3.00 \\
\hline
\end{tabular}

P.T. = Total loss; e.= Mean standard error

Table 2 - Volume Acquired, traded and losses recorded during guava commercialization in supermarket at the Chapadinha (MA), 2016.

\begin{tabular}{|c|c|c|c|c|c|}
\hline \multirow{2}{*}{ Fruit } & \multirow{2}{*}{$\begin{array}{l}\text { Vol. } \\
\text { Acquired } \\
(\mathrm{kg})\end{array}$} & \multirow{2}{*}{$\begin{array}{c}\text { Vol. } \\
\text { Commercialized } \\
(\mathrm{kg})\end{array}$} & \multirow{2}{*}{$\begin{array}{c}\mathrm{PT} \pm \mathrm{e} \\
(\%)\end{array}$} & \multicolumn{2}{|c|}{ Causes of Losses (\%) } \\
\hline & & & & Physiological & Mechanica \\
\hline Guava & 27 & 22 & $21.0 .0 \pm 2.48$ & 10.50 & 10.50 \\
\hline
\end{tabular}

P.T. = Total loss; e.= Mean standard error

It is important to emphasize mechanical injuries accelerate ripening and open "entry doors" for pathogens that reduce the shelf life of guava in the analyzed marketing environments. 
In summary, it is recommended to the training of traders or employees in postharvest best practices and business management; sanitization of environment and trading stands; effective planning of the amount offered, with attention to seasonality and population habits; adoption of low-cost storage technologies such as plastic film, waxes, and starch; and use of refrigeration when available and economically viable.

As expectations, it aims a greater public incentive to improve the roads and especially the expansion of the agricultural frontier of fruit in Maranhão, which is one of the largest Brazilian states, with climate and compatible consumer market, to guava exploration. This requires the adoption of efficient tax exemption strategies and rural credit provision and technical assistance, in order to producers become competitiveness with neighboring states like Ceará and Pernambuco, where the fruit production chain is a reality, as a source of income and jobs.

\section{Conclusions}

The estimated total losses for guava sold in Chapadinha (MA) were $17 \%$ for groceries stores and $21 \%$ in supermarkets.

The physiological injuries were the main causal agents of postharvest losses, especially the groceries stores, where they reached $14.00 \%$. Losses can be mitigated by the adoption of good postharvest practices and business management, which can be fostered and widespread by government incentive.

\section{References}

AGRIANUAL: Anuário da Agricultura Brasileira. São Paulo: FNP Consultoria e Comercio, 2015. p. 471.

ALMEIDA, E. I. B.; RIBEIRO, W. S.; COSTA, L. C.; LUCENA, H. H.; BARBOSA, J. A. (2012). Levantamento de perdas em hortaliças frescas na rede varejista de Areia (PB). Revista Brasileira de Agropecuária Sustentável, 2, 53-60, 2012.

AMORIM, D. ; PIRES, I. C. G.; FERRAO, G. E. ; ALMEIDA, E. I. B. . Análise da qualidade e do preço de hortaliças comercializadas no mercado varejista de Chapadinha (MA). Agrotrópica, v. 29, p. 151-156, 2017.

AMORIM, F. F. V. R. D.; GARRETO, F. G. D. S.; MENDES, K. D. R.; PIRES, I. C. G.; ALMEIDA, E. I. B. Desempenho da comercialização de abacaxi em Chapadinha/MA In: FARIAS, M. F.; FURTADO, M. B.; PARRA-SERRANO, L. J.; FREITAS, J. R. B.; FERRÃO, G. E. Tópicos em produção agrícola no leste maranhense: Livro comemorativo dos 10 anos do Curso de Agronomia CCAA/UFMA. 1 ed. São Luis, MA; EDUFMA, Cap. 24, p. 241-248. 2016.
BRACHMANN, A.; ANESE, R. O.; BOTH, V.; THEWES, F. R.; FRONZA, D. Atmosfera controlada para o armazenamento de goiaba cultivar 'Paluma'. Revista Ceres, Viçosa, v. 59, n.2, p. 151-156, mar/abr, 2012.

BRAZILIAN FRUIT - Programa de promoção das exportações das frutas brasileiras e derivados. Disponível em:

<http://www.brazilianfruit.org/newbrazilianfruit>.

Acesso em: 29 ago 2017.

BRUNINI, M. A.; CARDOSO, S. S. Qualidade de pitaias de polpa branca armazenadas em diferentes temperaturas. Revista Caatinga, Mossoró, v. 24, n. 3, p. 78-84, 2011.

CECCATO, C.; BASSO, C. Avaliação das perdas de frutas, legumes e verduras em supermercado de Santa Maria-RS. Disciplinarum Scientia Saúde, v. 12, n. 1, p. 127-137, 2012.

CHITARRA, M.I.F.; CHITARRA, A.B. Pós-colheita de frutos e hortaliças: fisiologia e manuseio. 2.ed. rev. e ampl. Lavras: UFLA, 2005. 785p.

CRISTOFOLI, N.; ARAÚJO, M.; FREIRE, D.; MAIA, J. Estimativa das perdas de frutas e hortaliças em uma rede varejista de Fortaleza-CE. In: 54은 Congresso Brasileiro de Química. Anais. Rio Grande do Norte, nov. 2014. Disponível em: <http://www.abq.org.br/cbq/2014/trabalhos/10/635119648.html>. Acesso em: 01 ago 2017.

D>.

EMBRAPA. Empresa Brasileira de Pesquisas Agropecúarias. A cultura da goiaba. $2^{\underline{a}}$ edição revista e ampliada - Brasília, DF : Embrapa Informação Tecnológica, 2010. 180 p. (Coleção Plantar, 66).

FERRÃO, G. DA E.; SILVA, L. R.; SOUSA, R. M. DE; PIRES, I. C. G.; ALMEIDA, E. I. B.; SOUZA, J. N. C. Comercialização da banana no município de Chapadinha (MA). In: FARIAS, M. F.; FURTADO, M. B.; PARRA-SERRANO, L. J.; FREITAS, J. R. B.; FERRÃO, G. E. Tópicos em produção agrícola no leste maranhense: Livro comemorativo dos 10 anos do Curso de Agronomia CCAA/UFMA. 1 ed. São Luis, MA; EDUFMA, Cap. 22, p. 230-238, 2016.

GONÇALVES, B. J. Monitoração por termografia infravermelha da qualidade pós-colheita de goiabas armazenadas sob refrigeração. Dissertação (Mestrado em Ciência dos Alimentos). Lavras, MG: UFLA, 2014. 125p.

GUERRA, A. M. N. D. M. Avaliação das principais causas de perdas pós-colheita de hortaliças comercializadas em Santarém, Pará. Revista Verde, v. 30, n. 2, p. 34-40, 2017.

NASCIMENTO, S. S.; MENDES, M. S.; SOUSA, A. N. S.; TOMM, T. F. R.; ALMEIDA, E. I. B.; GONDIM, M. M. S. Levantamento de perdas pós-colheita de frutas tropicais em Chapadinha (MA). In: FARIAS, M. F.; FURTADO, M. B.; PARRA-SERRANO, L. J.; 
FREITAS, J. R. B.; FERRÃO, G. E. Tópicos em produção agrícola no leste maranhense: Livro comemorativo dos 10 anos do Curso de Agronomia CCAA/UFMA. 1 ed. São Luis, MA; EDUFMA, Cap. 21, p. 230-238, 2016a.

PARISI, M. C. M.; HENRIQUE, C. M.; PRATI, P. Perdas pós-colheita: um gargalo na produção de alimentos. Pesquisa \& Tecnologia, v.6, n.2, 2012.

QUINTAL, S. S. R. Melhoramento da goiabeira P. guajava via metodologia de métodos mistos. Tese apresentada ao centro de Ciências e Tecnologias Agropecuárias da Universidade Estadual do Norte Fluminense Darcy Ribeiro. Campos dos Goytacazes, 2013.

RAMOS, D. P.; LEONEL, S.; SILVA, A. C.; SOUZA, M. E.; SOUZA, A. P.; FRAGOSO, A. M. Épocas de poda na sazonalidade, produção e qualidade dos frutos da goiabeira 'Paluma'. Semina: Ciências Agrárias, Londrina, v. 32, n. 3, p. 909-918. 2011.

ROCHA, R. H. C. et al. Qualidade do mamão 'formosa' submetido a diferentes temperaturas de refrigeração. Revista Caatinga, Mossoró, v.20, n. 1, p. 75-80, 2007.

SANTOS FILHO, E. M. et al. Caracterização da distribuição e algumas perdas de pós-colheita do maracujá amarelo produzido no munícipio de CuitéPB. Revista ACSA, Campina Grande, v. 10, n. 1, p. 07-13, jan - mar, 2014.

SANTOS, K.; VIEIRA, W. Destino final: o lixo. Comunicado especial: Abastecer Brasil, Associação Brasileira das Centrais de Abastecimento, n.5. p.812. 2011.

SEBRAE - Serviço de Apoio a Micro e Pequenas Empresas. As variedades de polpa vermelha desta fruta tropical são preferidas no Brasil, tanto para consumo in natura como para indústria. 2016. Disponível em: <https://www.sebrae.com.br/sites/ PortalSebrae/art artigos/o-cultivo-e-o-mercado-dagoiaba,

d3aa9e665b182410VgnVCM100000b272010aRCR

SEBRAE. Horticultura - Desperdício de Alimentos é preocupação mundial, 2011. Disponível em: <http://www.sebrae.com.br/setor/horticultura>. Acesso em: 26 mar 2017.

SENAI - Serviço Nacional de Aprendizagem Industrial de frutas e hortaliças. São Paulo: SENAISP Editora, 2016, $136 \mathrm{p}$.
SENHOR, R. F. et al. Fatores de pré e pós-colheita que afetam os frutos e hortaliças em pós-colheita. Revista Verde, Mossoró - RN, v. 4, n. 3, p.13-21, jul./set. 2009.

SILVA, H. S.; ROCHA, R. H. C.; SOUSA, F. A. Qualidade de goiabas cv. 'paluma' submetidas a injúrias mecânicas e frigoarmazenamento. Revista Caatinga, Mossoró, v. 26, n. 1, p. 49-54, jan.-mar, 2013.

SILVA, Helton S.; MOREIRA, Inácia dos Santos; FURTUNATO, Tádria C. S.; ROCHA, Railene H. C.; SOUSA, Francisco D. A. Estádios de maturação e danos mecânicos na goiaba comercializada no Sertão da Paraíba. Revista Verde (Pombal - PB Brasil) v. 10, n.2, p. 01 - 08, abr-jun, 2015.

SINGH, S.P.; PAL, R.K. Controlled atmosphere storage of guava (Psidium guajava L.) fruit. Postharvest Biology and technology, 47:296-306, 2008.

SOUZA, A. N. S,; ALMEIDA, E. I, B.; NASCIMENTO, S. S.; MENDES, M. S.; SOUSA, W. S.; MELO, P. A. F. R. Perdas pós-colheita de hortaliças no merrcado varejistas de Chapadinha, Maranhão, Brasil. Revista Agrotrópica, Centro de Pesquisas do Cacau, Ilhéus, Bahia, Brasil, v 30, n 2, maio a agosto de 2018.

TIETFEL, Z.; LEWINSOHN, E.; FALLIK, E.; PORAT, R. Importance of storage temperatures in maintaining flavor and quality of mandarins. Postharvest Biology and Technology. Amsterdam, v.64, n. 1, p. 175-182, 2012.

TOMM, T. F. R.; SOUSA, A. N. S.; NASCIMENTO, S. S.; MENDES, M. S.; ALMEIDA, E. I. B.; GONDIM, M. M. S. Cenário de comercialização e estimativa de perdas pós-colheita de frutas temperadas em Chapadinha (MA). In: FARIAS, M. F.; FURTADO, M. B.; PARRA-SERRANO, L. J.; FREITAS, J. R. B.; FERRÃO, G. E. Tópicos em produção agrícola no leste maranhense: Livro comemorativo dos 10 anos do Curso de Agronomia CCAA/UFMA. 1 ed. São Luis, MA; EDUFMA, Cap. 23, p. 230-238. 2016a.

VIEIRA, S. M. J.; COUTO, S. M.; CORRÊA, P. C.; SANTOS, A. E. O.; CECOM, P. R.; SILVA, D. J. P. Características físicas de goiabas (Psidium guajava L.) submetidas a tratamento hidrotérmico. Revista Brasileira de Engenharia Agrícola e Ambiental, v. $12, \quad$ n. $4, \quad$ p.408-414, 2008. 